\title{
O Ele, os K.'s, o homem de boa vontade: Arendt, leitora de Kafka
}

\author{
The He, the K.'s, the Man of Good Will: Arendt, reader of Kafka
}

DOI: $10.20873 / \mathrm{rpv} 6 \mathrm{n} 2-12$

\section{Lara Rocha}

Orcid: 0000-0002-2865-196X

Email: larafr87@gmail.com

\begin{abstract}
Resumo
O presente artigo analisa a leitura de Hannah Arendt sobre os textos de Franz Kafka, o que será feito a partir do prefácio de Entre o passado e o futuro, dos ensaios Franz Kafka: uma reavaliação e $O$ judeu como pária: uma tradição oculta, além das narrativas kafkianas Descrição de uma luta, O Processo, $O$ Castelo e da parábola Ele, identificando tanto o que as vincula como o definhamento do humano retratado pelo escritor. Porquanto o absurdo que reveste o cenário descrito por Kafka é percebido por Arendt como um presságio dos horrores praticados pelos regimes totalitários, nossa hipótese é que discutir a leitura da autora sobre os textos kafkianos auxilia a compreensão sobre as consequências desastrosas que as relações sociais podem acarretar e a desfiguração fomentada pela burocracia como aparelho organizacional e forma de governo que normaliza os procedimentos de rotina, os massacres administrativos, a obediência cadavérica e os processos infindáveis baseados em legislações superiores, utilizados como meios de gerir indivíduos desarraigados, indistinguíveis e massificados.
\end{abstract}

\section{Palavras-chave}

Hannah Arendt. Franz Kafka. Burocracia. Sociedade. Pensamento. Assimilação.

\begin{abstract}
This article analyze Hannah Arendt's reading of Franz Kafka's texts, which will be done from the preface to Between the past and future, from the essays Franz Kafka: a revaluation and The Jew as Pariah: A Hidden Tradition, in addition to the Kafkaesque narratives Description of a struggle, The Process, The Castle and the parable $\mathrm{He}$, identifying both what binds them and the wasting of the human portrayed by the writer. As the absurdity that covers the scenario described by Kafka is perceived by Arendt as an omen of the horrors practiced by totalitarian regimes, our hypothesis is that discussing the author's reading of Kafka's texts helps to understand the disastrous consequences that social relations can entail and the disfigurement fostered by bureaucracy as an organizational apparatus and form of government that normalizes routine procedures, administrative massacres, cadaveric obedience and endless processes based on superior legislation, used as a means of managing uprooted individuals, indistinguishable and massive.
\end{abstract}




\section{Keywords}

Hannah Arendt. Franz Kafka. Bureaucracy. Society. Thought. Assimilation.

\section{Introdução: Kafka, um pária}

Para Hannah Arendt, as experiências são a gênese do pensamento. Sendo assim, pensar o que estamos fazendo, imperativo filosófico de primeira grandeza, deve ancorar-se não apenas no discurso conceitual filosófico tradicional, mas também nas diversas formas de expressar-se frente aos acontecimentos. Esta abertura facilita a utilização de outras linguagens na reflexão sobre a política, dentre as quais se destaca a literatura. Com efeito, autores como David Rousset, Gotthold Ephraim Lessing, Bertold Brecht, Isak Dinesen e Franz Kafka, por exemplo, são marcantes em sua proposta de analisar os legados deixados pela novidade totalitária1.

A alusão a estes escritores, além de demonstrar seu conhecimento e sensibilidade literária, se justifica pela constatação de que o fio de Ariadne que nos vincula à tradição foi rompido e, diante do horror indizível que caracteriza os eventos do século XX, os conceitos tradicionais não podem mais ser considerados os únicos meios a partir dos quais os acontecimentos políticos são analisados. Nestes termos, porquanto ampliar as perspectivas sobre estes eventos auxilia a compreendê-los, o apoio da literatura se desvela como uma ferramenta que nos acompanha nesta hercúlea trajetória.

Poucos escritores são tão recorrentes nas obras de Arendt quanto Franz Kafka. Suas considerações sobre o desenvolvimento científico como possibilidade de desfiguração do humano mencionado em A conquista do espaço e a estatura humana, sua parábola sobre as forças que empurram os homens em direções opostas, destacada no prefácio de Entre o passado e o futuro e em $A$ vida do espírito, seu relato sobre os problemas ínsitos à assimilação dos judeus às

\footnotetext{
${ }^{1}$ Arendt cita diversos outros escritores: Goethe, com seu Fausto, e Shakespeare, com Ricardo III, Iago e Macbeth, são mencionados em A vida do espírito. Nos cursos "Questões contemporâneas", ministrado em Berkeley em 1955 e "Experiências políticas do século XX", ofertado em Cornell em 1966 e New School of Social Research dois anos depois, George Orwell, T.W. Lawrence, Ernest Hemingway e Thomas Mann serviam como referências para compreender as catástrofes políticas do século XX (Cf. LAFER, 2007).
} 
diversas comunidades nacionais, pontuados em 0 judeu como pária: uma tradição oculta e a antevisão kafkiana sobre a radicalidade da burocracia, empreendida no ensaio anterior e em Franz Kafka: uma reavaliação, são alguns dos diálogos que a autora estabelece com o literato.

Dois motivos principais podem justificar essa recorrente menção ao escritor. Em primeiro lugar, Arendt aponta que Kafka é um romancista que escapa ao sentido oitocentista do termo, já que "a base do romance clássico era a aceitação da sociedade como tal, a submissão à vida como se dá, a convicção de que a grandeza do destino ultrapassa os vícios e as virtudes" (ARENDT, 2008, p. 106). Na verdade, ele é o “último dos grandes poetas da Europa” (ARENDT, 2016, p. 521) por identificar que relatar o caráter idílico da sociedade burguesa não se coadunava com o medonho cenário dos séculos XIX-XX. A percepção kafkiana de que sociedade é “um ninguém em traje a rigor" (KAFKA, 1985, p. 47) e a ausência de linearidade temporal nos seus escritos, nos quais presente, passado e futuro disputam permanência, partem do mesmo solo em que Arendt identifica a quebra do vínculo com a tradição.

Por outro lado, Kafka é um pária². Interessava-o denunciar a posição outlaw $w^{3}$ dos judeus, o que fez tanto através da participação no movimento sionista como da escrita de $O$ Castelo, romance em que o protagonista era um judeu, lidando com problemas tipicamente judeus, como o desejo de ser indistinguível, alguém que desfruta de uma existência comum, sem ter que escolher a excepcionalidade ou o abandono. Ao acreditar que os direitos humanos básicos deveriam ser assegurados naturalmente, e não como uma excepcionalidade ou um ato de magnanimidade, ele denunciou o desloucamento de um mundo em que nenhuma destas hipóteses era mais possível (Cf. ANDERS, 2007).

A leitura arendtiana sobre Kafka não deve ser compreendida de modo desassociado da influência que o escritor exerceu sobre seus amigos: Walter Benjamin dedicou-se às análises

\footnotetext{
${ }^{2}$ Sobre as distinções entre o parvenu (aquele que nega o judaísmo e vê na inserção social uma saída para sua situação), o pária (que vive em situação de acosmia, numa postura outsider) e o pária consciente (aquele que, mesmo excluído do mundo, não rompe com ele, fazendo de sua posição o ponto nevrálgico para denunciar as injustiças, os perigos ínsitos ao não-pertencimento e a opressão), ver Aguiar (2001) e Leibovici (1989).

${ }^{3}$ Arendt utiliza o termo outlaw, cuja livre-tradução equivale a "fora-da-lei" não para designar criminosos, mas para indicar os judeus, grupo cujo nenhum código jurídico conseguiu assegurar seus direitos básicos ou mesmo a preservação de suas vidas. Os outlaw, na leitura arendtiana, são aqueles que a proteção jurídica não abriga, que estão à margem da salvaguarda legal.
} 
sobre sua obra no ensaio Franz Kafka. A propósito do décimo aniversário de sua morte (BENJAMIN, 2017). O primeiro marido de Arendt, o jornalista Günther Anders, foi um proeminente comentador dos textos kafkianos. W. H. Auden afirmou que: "se tivesse de mencionar o autor que tem para com a nossa época aproximadamente a mesma relação que Dante e Shakespeare tiveram para com a sua, Kafka é o primeiro nome em quem eu pensaria" (RODRIGUES in KAFKA, $1985, \mathrm{~s} / \mathrm{p})$.

Assim como seus contemporâneos, Arendt percebeu que a novidade kafkiana reside tanto na sua arte narrativa, que fez dele um romancista dos escombros, quanto por identificar os espectros que subjaziam a sociedade e as novas formas de administração que se estabeleciam, frente às quais "há esperança, mas não para nós" (BENJAMIN, 1987, p. 142). Segundo Knott (2005), mesmo que Kafka fosse uma unanimidade entre seus amigos, não é possível precisar quando Arendt teve seu primeiro contato com os textos do autor; porém, isso deve ter acontecido nos anos em que ela se refugiou em Paris. Entretanto, já no início de sua estadia em Nova Iorque ela participou da tradução dos Diários do autor feita pela editora Schocken, responsável pela publicação de obras de autores judeus nos Estados Unidos (ECCEL, 2019).

Deixando-nos conduzir pela leitura arendtiana sobre o escritor, que gravita em torno da condição do mundo moderno e da metamorfose do homem do período, este artigo exporá as principais interpretações que a teórica política apresenta sobre as narrativas kafkianas: a reflexão sobre a sociedade, com base no conto Descrição de uma luta, o exame sobre a lacuna entre o passado e o futuro, extraída da parábola Ele, a análise da burocracia, retratada tanto em $O$ Processo quanto em $O$ Castelo e, por fim, a apresentação do problema da assimilação judaica, retirado de $O$ Castelo.

\section{“A sociedade é um ninguém em traje a rigor”}

No conto Descrição de uma luta ${ }^{4}$, o autor descreve como as interações sociais podem trazer consequências desastrosas. 0 protagonista da história, um herói sem nome, cuja rotina

\footnotetext{
${ }^{4}$ Sobre o período em que Kafka escreveu a obra, Baeckes (in KAFKA, 2020, p. 8) destaca que: "A vida emocional de Kafka foi conturbada, e ele teve vários noivados e amores infelizes. Essas circunstâncias acentuaram o sentimento de solidão e desamparo que jamais o abandonaria e que se manifestou nos fragmentos publicados em 1909 sob o
} 
se resume "ao dia todo no escritório, as noites nas festas e nas ruas" (KAFKA, 1985, p. 13), estava em um salão quando conheceu um homem de vida igualmente normal e monótona, "levo uma vida muito normal. Não há nada de errado nela, tudo o que faço é considerado correto e geralmente aprovado [...], a boa sorte não me faltou" (KAFKA, 1985, p. 64), com quem se juntou para uma conturbada caminhada, envolvida por conversas, reviravoltas, encontros oníricos, lembranças e confrontos físicos.

A sociedade descrita no conto é composta por ninguéns, por indivíduos igualmente impotentes, cabisbaixos e desimportantes, de modo que a única coisa que os diferencia é a natureza de suas agruras. Porém, ainda assim - e talvez, justamente por isso -, ela faz com que uns se sintam menos reais do que outros. Na leitura de Arendt sobre a obra, fazer com que alguns duvidem da veracidade de sua própria existência, reduzindo-os ao status de uma indubitável insignificância, é o maior mal que as relações sociais podem conferir a indivíduos e grupos (ARENDT, 2016)5. "Não vem ninguém. Não fiz mal a ninguém, mas ninguém me ajuda. Uma súcia de ninguéns [...]. Todos vestidos a rigor" (KAFKA, 1985, p. 27).

Marcados como indésirables, resta a estes homens e mulheres que têm a veracidade de sua existência questionada refugiarem-se em alguns espaços: a primeira dessas possibilidades seria a formação de uma contrassociedade constituída de párias. Porém, Kafka, como um apaixonado pelo mundo, não considerava que esquivar-se dele seria a solução adequada para estes indivíduos já mantidos à margem. Em contraposição a esta primeira solução, outra saída seria refugiar-se na contemplação da natureza e das artes - o que acarretaria, novamente em uma postura outsider. Ademais, com o desenvolvimento técnico-científico, a natureza teve ameaçado o seu caráter de superioridade, não podendo mais abrigar os ninguéns produzidos pela

título Descrição de uma luta (Beschreibung eines Kampfes). O livro seria publicado na íntegra apenas em 1936. Nessa inquietante e perturbadora narração, que passou quase despercebida [...], o mundo dos sonhos adquire lógica desconcertante e obstinada em meio ao mundo real".

${ }^{5}$ Uma das histórias de Descrição de uma luta ilustra essa suspensão da existência. O protagonista narra o momento em que estava em um salão quando, de repente, foi tomado por uma estranha sensação de felicidade, que o motivou a querer tocar piano, mesmo sem sabê-lo. A multidão que ali estava se divertia com a situação. Após levá-lo até o palco, o afastava elegante e furtivamente do piano, até que o anfitrião o conduziu até a porta. Saindo do salão com a sensação antagônica de, por um lado, ser tratado com cortesia e, por outro, ser indesejável, indagou: "o que faz com que todos ajam como se fossem reais? Estão tentando fazer-me acreditar que não sou real, aqui, absurdamente de pé, na calçada?" (KAFKA, 1985, p. 54). 
sociedade. Por outro lado, a arte é um produto social e, como todos os seus artifícios, tende a ser abandonada e perder atualidade cada vez que "coisas novas" surgem, num movimento de uso-descarte em que os ninguéns da sociedade também são engolfados.

Uma das historietas narradas no conto relata que os tempos difíceis em que vivem os personagens podem ser simbolizados pela instabilidade dos pilares que sustentam as cidades fictícias representadas em Descrição de uma luta - alicerces que metaforicamente simbolizam as verdades que tradicionalmente sustentaram a política e a sociedade -, fazendo com que o desmoronamento de suas frágeis construções imponha aos homens que ali residem caminhar sobre ruínas. 0 mais impressionante, para o narrador da historieta (o interlocutor do protagonista) é que apenas ele parece se importar com tal cenário: "Nessas ocasiões, eu caminho sobre as ruínas, perguntando a todos os que eu encontro: 'Como pôde acontecer isso? Na nossa cidade - uma casa nova - quantas até agora? Pensem nisso!' E ninguém pode me responder" (KAFKA, 1985, p. 47).

Nessa sociedade formada por ninguéns em traje a rigor, conviver com o inaudito normaliza a indiferença. A seguinte parábola sobre o "mundo que se desfaz" sob os pés dos "pequenos habitantes das ruínas" (KAFKA, 2021, p. 23) - que certamente poderia ter sido descrita por alguma testemunha dos movimentos totalitários - também foi relatada pelo interlocutor do herói sem nome kafkiano.

Frequentemente as pessoas caem na rua e morrem. Enquanto isso, os comerciantes abrem as portas das lojas repletas de mercadorias, saem apressadamente, levam o morto para uma casa, saem outra vez sorrindo, e a conversa começa: 'Bom dia - é um dia horrível - estou vendendo um lote de lenços - ah, sim, a guerra'. Corro para casa e, depois de erguer a mão timidamente, várias vezes, afinal bato na pequena janela do zelador: 'Bom dia', digo eu, 'soube que um homem morto foi trazido para cá. Poderia ter a bondade de me deixar vê-lo?' E quando ele sacode a cabeça, como se não fosse capaz de tomar uma decisão, eu acrescento: 'Tenha cuidado, sou da polícia secreta e insisto em ver o morto imediatamente!' Ele não parece mais indeciso. 'Saia daqui', grita o homem [...]. Não há nenhum homem morto. Talvez na casa do lado'. Levanto a aba do chapéu e me afasto. (KAFKA, 1985, p. 47)

A sociedade composta por ninguéns, ou seja, por indivíduos que abdicaram de sua capacidade de distinguirem-se através de atos e palavras para se comportar de acordo com os ditames sociais, fez da discriminação "a arma pela qual se pode matar homens sem qualquer derramamento de sangue" (ARENDT, 2016, p. 490). Se adequar a estes padrões desempenha papel 
importante no modo como os sujeitos representam a si mesmos, de modo que para obter aprovação social eles tendem a se acomodar irrefletidamente a tais modelos. Ademais, "o homem é um animal social, e a vida não é fácil para ele quando os liames sociais são cortados. Os padrões morais são mantidos muito mais facilmente na tessitura de uma sociedade. Pouquíssimos indivíduos têm a força necessária para conservar sua própria integridade, se seu status social, político e legal estiver completamente confuso" (ARENDT, 2016, p. 487).

Nesse cenário, o Sr. Cohn, judeu descrito por Arendt em Nós, os refugiados que, para se assimilar às comunidades locais, foi um alemão patriota, um tcheco convicto, um austríaco orgulhoso, um francês exemplar, até que se esqueceu de ser ele mesmo e, apesar de tais esforços, não foi bem aceito em lugar nenhum, poderia ser um personagem das histórias kafkianas, em especial dos diálogos e encontros oníricos, irreais, mas com uma aura inquestionável de realidade, tal como os descritos no conto mencionado.

0 que Arendt identifica em Descrição de uma luta é o ataque de Kafka tanto à sociedade quanto à posição de fuga do mundo, postura que, ainda na primeira década do século XX, o autor constatou como incapaz de garantir a sobrevivência de grupos perseguidos. Dito de outro modo, recorrer à contemplação não é suficiente nem para assegurar aos indivíduos o estatuto de portadores de dignidade, nem tampouco de lhes manter a salvo de movimentos antipolíticos. Para o escritor, a única coisa capaz de fazê-lo, então, era o pensamento, "a única arma da qual, na opinião de Kafka, o pária é dotado ao nascer em sua luta vital contra a sociedade" (ARENDT, 2016, p. 514).

As consequências das relações sociais - estabelecidas, no caso, nos salões europeus também foi o mote de um texto da juventude de Arendt: a biografia de Rahel Varnhagen. Nela, o dilema da protagonista também era pertencer ao mundo, o que era feito através da vida social, da contemplação da cultura e das artes ou da excepcionalidade do gênio. A variação entre uma postura outsider e insider que forma o pano de fundo a partir do qual a protagonista arendtiana se move somente é possível porque se passa em uma sociedade massificada, na qual "novas formas de interação social, padrões de associação, hábitos e costumes" (BENHABIB, 2003, p. 29), foram formados a partir da alienação do mundo, de um lado, e da glorificação do trabalho, de outro. 
Essa sociedade optou pela fuga do mundo, postura outsider que Kafka condena em Descrição de uma luta: se "os salões berlinenses [se apresentavam] como um espaço em que as diferenças econômicas e sociais se desintegravam, deixando aberta a possibilidade de cada um se apresentar por aquilo que é" (ADVERSE, 2013, p. 83), Kafka não vislumbrava, através da inserção nestes espaços, uma saída para o pequeno habitante dos escombros, expulso por ser indesiráble. Ao contrário, a possibilidade de distinguir-se escapa aos ritos sociais e românticos e se espraia no exercício do pensar por si próprio, saída também prenunciada na obra sobre Rahel Varnhagen. “Tudo depende do pensar [...]. O pensar por si próprio liberta os objetos e sua realidade, cria uma esfera de puras ideias e um mundo que é acessível, sem conhecimento ou experiência, a qualquer ser racional [...]. A razão pode libertar dos preconceitos do passado e orientar o futuro de uma pessoa" (ARENDT, 1994, p. 20). Nesse sentido, os salões frequentados pelo personagem anônimo de Kafka guardam semelhanças com aqueles nos quais Rahel Varhagen buscava diferenciar-se.

Certamente, o pensar é a arma do pária para enfrentar os preconceitos. Porém, diferente da Rahel de Arendt, que acreditava, por outro lado, que a fuga interior poderia oferecer um abrigo àqueles que não encontram lugar no mundo ${ }^{6}$, o herói sem nome de Kafka acredita que o pensamento só pode realizar sua potencialidade na convivência com os demais e no confronto com a realidade, desnuda, medonha e oculta.

\section{O Ele e a lacuna entre o passado e o futuro}

"Nossa herança nos foi deixada sem nenhum testamento". É com esta constatação feita por René Char que Arendt inicia o prefácio de Entre o passado e o futuro. Compreender as catástrofes políticas do século XX impôs à autora a constatação de que o fio que vinculava às últimas gerações aos tesouros perdidos do passado fora rompido.

\footnotetext{
6 "Se o pensar ricocheteia sobre si mesmo e encontra seu único objeto na própria alma, torna-se reflexão, e adquire (desde que permaneça racional) uma semelhança de poder ilimitado, ao mesmo tempo em que se isola do mundo, se desinteressa deste, entrincheira-se diante do único objeto 'interessante': o próprio interior. No isolamento alcançado pela reflexão, o pensar torna-se ilimitado porque não é mais molestado por qualquer coisa exterior; porque não há mais qualquer demanda de ação, cujas consequências restringem até mesmo o espírito mais livre [...]. A realidade não pode oferecer nada novo; a reflexão já antecipou tudo." (ARENDT, 1994, p. 21).
} 
Partindo do pressuposto de que "as metáforas são o pão de cada dia de todo pensamento conceitual" (ARENDT, 2004, p. 73), é possível identificar o que a sentença de Char denuncia: porquanto o testamento se refere à relação de bens dados gratuitamente a um herdeiro, legando posses a ele oriundas do passado em vista de um uso futuro, sem tal documento é inviável conhecer o valor dos tesouros herdados, fadando-os à má utilização. Substituindo o termo tesouros por tradição, pode-se perceber que os acontecimentos políticos do século XX trouxeram à luz aquilo que Tocqueville denunciou no século XIX: o elo que vinculava passado e futuro fora irremediavelmente rompido ${ }^{7}$.

A crise instalada com esta ruptura, para Arendt, foi descrita com exatidão pela parábola Ele, retratada pela autora como uma autêntica "parabolaí, lançada em torno do incidente como raio luminoso que [...] possui o poder radiográfico de desvelar sua estrutura que, em nosso caso, consiste nos processos recônditos da mente" (ARENDT, 2016, p. 33). 0 texto kafkiano retrata duas forças antagônicas que pressionam um Ele, uma o acossando por trás, enquanto a outra lhe bloqueia a frente. Permanecendo entre ambas, ele peleja contra as duas, ao passo em que cada uma delas lhe auxilia na luta contra a outra. Imerso nesse embate, o desejo do Ele é que, num rompante inesperado, possa sair do campo de combate, erguido "por conta de sua experiência de luta, à posição de juiz sobre os adversários que lutam entre si" (ARENDT, 2016, p. 33).

Arendt interpreta que a luta do Ele começa quando a ação já havia sido iniciada - ou seja, quando as duas forças já duelavam. Por outro lado, seu fim não é narrado por Kafka, mas possível apenas como um exercício de imaginação de seus leitores. Porém, exatamente neste ponto surge um problema capital: se a função da mente é, através da compreensão, possibilitar a reconciliação entre aquele que pensa e o mundo, como proceder quando nenhuma delas é possível? Será que o Ele estaria, então, fadado a permanecer envolvido na luta estabelecida pelas forças antagônicas?

\footnotetext{
7 “À medida que você sobe e desce degraus, sempre pode segurar no corrimão para não cair. Mas nós perdemos esse corrimão [...]. Esse assunto de que a tradição foi quebrada, de que o fio de Ariadne foi cortado, não é algo tão novo quanto eu faço parecer. Afinal, foi Tocqueville quem disse que 'quando o passado cessa de lançar luz sobre o futuro, o espírito do homem vaga na escuridão'. Essa é a situação desde meados do século XIX" (ARENDT, 2021, p. $530)$.
} 
Arendt identifica que as forças que atuam sobre o Ele são o passado e o futuro, enquanto o personagem luta para se manter em seu espaço atual, ou seja, situado no presente, atualizado como o momento que "escapa da transitoriedade da sucessão de agoras apenas no pensamento. Sem pensamento não há presente. E sem o presente não há passado nem futuro que, como tal, constituem apenas memória e esperança" (ARENDT, 2006, p. 724). É a presença do Ele que faz a luta existir, pois na sua ausência as forças ou teriam se neutralizado, ou se destruído.

Do ponto de vista do homem, que vive sempre no intervalo entre o passado e o futuro, o tempo não é um contínuo, um fluxo de ininterrupta sucessão; é partido ao meio, no ponto onde 'Ele' está; e a posição dele não é o presente, na sua acepção usual, mas uma lacuna no tempo, cuja existência é conservada graças à 'sua' luta constante, à 'sua' tomada de posição contra o passado e o futuro. Apenas porque o homem se insere no tempo, e apenas na medida em que defende seu território, o fluxo indiferente do tempo parte-se em passado, presente e futuro. (ARENDT, 2016, p. 37)

A atividade que a parábola retrata é o espaço ocupado pelos homens enquanto pensam. O Ele, ao pensar, dá um salto para além do campo de batalha, rumo ao infinito, se tornando momentaneamente atemporal e atingindo o estágio de maior atividade de que é capaz. Portanto, "carregamos em nós algo atemporal, embora esse atemporal seja mantido em existência pelo temporal. 0 aparato funcional é mortal, mas a atividade do pensamento não" (ARENDT, 2006, p. 629). Na medida em que pensa, o Ele vive na lacuna aberta pelo espírito entre o passado e o futuro, espaço em que "cada novo ser humano, inserindo-se entre um passado infinito e um futuro infinito deve descobri-lo e laboriosamente pavimentá-lo de novo" (ARENDT, 2016, p. 40). Como Kafka considerava o pensamento, em sua essencial vinculação com a experiência, a parte mais vívida da realidade, concebia-o como a arma do pária em sua luta contra a sociedade, tal como defendeu em Descrição de uma luta.

Nesse sentido, cada vez que pensamos atualizamos a sentença de Char e nos vemos envoltos na herança que recebemos sem testamento. Arendt identifica, porém, que a dificuldade ínsita à luta do Ele é que não estamos preparados para nos instalar na incômoda lacuna em que ocorre a peleja, pois este espaço, que antes foi ocupado pela tradição, após o rompimento do fio que vinculava os homens ao passado, deixou de ser um predicativo exclusivo do pensar para se tornar a "realidade tangível e perplexidade para todos, isto é, um fato de importância política" (ARENDT, 2016, p. 40). 
A experiência-pensamento a qual a parábola recorre não tem vinculação com a cognição ou com quaisquer processos de inferência lógica, mas refere-se ao diálogo entre eu e eu-mesmo que potencialmente se origina a cada vez que os homens se espantam com a realidade. Tanto para Arendt quanto para Kafka é o confronto com o mundo que anima o pensamento, de modo que as experiências oriundas deste contato são os marcos a partir dos quais esta atividade deve se orientar. 0 salto aspirado pelo Ele é o esforço por compreender o seu entorno, o que é descrito por Arendt a partir do paralelograma de forças, a imagem gráfica que mais se aproxima do movimento jamais completado rumo ao infinito contínuo do nunc stans (ARENDT, 2014).

Sem o homem não haveria tempo. 0 homem penetrou (ou se interpôs) no incessante movimento circular do universo só porque esse movimento se depara com ele e se limita a ele; o homem é o presente em que o passado e o futuro estão separados, o passado que o impulsiona e o futuro que parece rejeitá-lo. E precisamente o espaço intermediário, aquele que faz a mediação entre o passado e o futuro, se atualiza no pensamento: o pensamento volta a pensar o passado e antecipa o pensar no futuro. Os dois [...] não existiriam sem o pensamento (ARENDT, 2006, p. 724).

À medida que salta, o Ele é agente, e não mais um mero padecente das forças que se entrecruzam. Ao fazê-lo, é também expectador do grande jogo pois, ao assumir a posição de juiz, consegue observar o evento-embate. Se colocando na posição ideal para o espectador, ou seja, entre o passado e o futuro, o homem pode contemplar a ambos - mesmo com a ruptura com a tradição. Através do pensamento é possível, então, apontar semelhanças entre o protagonista anônimo de Descrição de uma luta e o Ele kafkiano.

Por outro lado, o campo de batalha é uma metáfora que representa a situação do homem moderno: se a lacuna entre passado e futuro se apresenta como um espaço não mais ocupado pela tradição, isso significa que tal hiato é habitado pelos sobreviventes, caminhantes do presente, "seres perdidos, não mais sustentados pelo passado e pelo futuro, não mais pertencentes ao fluxo da história, não mais protegidos pela lei" (ERDLE, 2016, p. 317). O Ele, retrato do homem contemporâneo, não possui nada além do agora e, apartado do passado e do futuro, o mais provável é que sucumba de exaustão.

Segundo Eccel (2019), Arendt identifica que mesmo que o contexto retratado por Kafka se situe em um porvir, o fato do escritor ser um mensageiro do futuro indica o ponto nevrálgico de sua própria modernidade: o trânsito entre passado, presente e futuro, posição nômade que 
deixa de se restringir ao pensamento e se converte na posição do homem moderno. Aliás, "é precisamente esta inserção, esse ponto de ruptura no fluxo indiferente do tempo, que faz do homem o início de um initium" (ERDLE, 2016, p. 308).

\section{O Processo e o criminoso sem crime}

O Processo relata a história do banqueiro Joseph K. que, na manhã do domingo de seu trigésimo aniversário, foi surpreendido com a notificação de uma acusação que ele não entendia e frente a qual tinha que se defender juridicamente. Assim, a história gravita em torno de suas tentativas de comprovar sua inocência. Porém, todo seu esforço foi em vão e, um ano após a instauração do inquérito, o romance termina com sua execução, a qual ele se submete sem resistência.

Todas as pessoas com as quais K. se deparou no decorrer do romance faziam parte do tribunal superior, frente o qual já estava condenado: o pintor, as crianças, o padre, o chefe do cartório, o diretor adjunto e os contínuos do banco eram, na verdade, membros da organização. Nesta administração, cujos "altos funcionários se escondem [...], não é possível se defender, é melhor fazer logo a confissão" (KAFKA, 2020, p. 130-131).

O protagonista do romance profere um discurso elucidador sobre o funcionamento da organização oculta que o acusava em sua audiência de instrução:

Não resta dúvidas que por trás de todas as declarações deste tribunal [...] encontra-se uma grande organização. Uma organização que não apenas emprega vigias corruptos, inspetores e juízes de instrução [...], mas sustenta, inclusive, uma magistratura de grau elevado, com um séquito inumerável de contínuos, escriturários, gendarmes e outros auxiliares, até mesmo de carrascos. E qual o sentido dessa organização? Ela consiste em deter pessoas inocentes e encaminhar contra elas um processo sem sentido e, na maior parte das vezes, sem resultado. Como poderia ser evitada, diante da falta de sentido do todo, a corrupção do funcionalismo envolvido? (KAFKA, 2020, p. 63)

Esse grande organismo se mantinha através de uma hierarquia rígida formada por escalões incontáveis e imprevisíveis, setorialização que fazia com que os procedimentos fossem secretos até mesmo para os funcionários dos escalões mais baixos. 0 relato kafkiano - que lembra a descrição das atividades de Eichmann contidas na obra Eichmann em Jerusalém - ganha contornos de antevisão quando exposta a seguinte passagem d' O Processo: 
O procedimento diante da corte de justiça era secreto também para os funcionários do baixo escalão, por isso era impossível para eles acompanharem algum dia plenamente os assuntos que eles mesmos examinavam [...]; a causa judicial surge, em seu campo de visão, sem que eles saibam de onde vem, e segue adiante sem que fiquem sabendo para onde vai [...]. Eles têm permissão para se ocupar apenas da parte do processo que a lei lhes destina, e na maior parte das vezes eles sabem menos daquilo que acontece a seguir, ou seja, dos resultados de seu próprio trabalho, do que a defesa, que via de regra ainda permanece ligada ao acusado até o fim do processo. (KAFKA, 2020, p. 145)

A organização retratada em $O$ Processo pode ser compreendida a partir da lenda descrita no penúltimo capítulo do livro, no diálogo entre o padre e Joseph $\mathrm{K}^{8}$. A historieta relata que diante da lei existe um porteiro e que, em um determinado dia, um camponês pediu sua autorização para entrar no espaço, obtendo como resposta que, naquele momento, seu ingresso era proibido. Porém, como as portas da lei permanecem abertas, o porteiro se postou na lateral da entrada, local em que o camponês seguiu por anos, oras tentando ver o que se passava no interior (ao que foi avisado que é impossível vislumbrá-lo, seja porque existem porteiros em cada repartição, seja porque a luz da lei ofusca os olhos humanos), oras tentando subornar o funcionário para facilitar sua entrada. Como os seus esforços são vãos, ele permanece no local até que, já sucumbindo ao cansaço, indaga o porteiro porque apenas ele buscou adentrar na lei durante tanto tempo. 0 funcionário responde que aquela porta havia sido feita apenas para ele e que, como já era moribundo, esta poderia ser fechada e o seu ofício, enfim, havia sido cumprido.

Ao explicar a lenda, o sacerdote afirma a K. que o porteiro apenas cumpriu ordens e, portanto, não fez mais do que realizar com excelência a sua função. Outras características do funcionário podem ser depreendidas da narrativa9: 1) "Ele ama a exatidão e exerce seu ofício com severidade" (KAFKA, 2020, p. 248), pois jamais deixa o seu posto e executa suas funções até o final, quando, enfim, tranca a porta; 2) "Ele tem consciência da importância de seu ofício" (KAFKA, 2020, p. 248), porquanto se compreende como um representante da lei, fazendo parte dela; 3) "Ele tem veneração por seus superiores" (KAFKA, 2020, p. 248), pois afirma que faz

\footnotetext{
80 apreço de Kafka sobre a lenda de $O$ Processo aparece em seus Diários, no relato do dia 13/12/1914: “Em vez de trabalhar - escrevi apenas uma página (exegese da lenda) - li um pouco dos capítulos prontos e os achei bons, em parte. Sempre consciente de que todo sentimento de satisfação e felicidade - que é o que sinto sobretudo no caso da lenda - precisa ser pago, e, aliás, a fim de jamais permitir descanso, pago a posteriori" (KAFKA, 2021, p. 410).

${ }_{9}^{9}$ As características do porteiro podem ser comparadas ao retrato de Eichmann retraçado por Arendt (2017), o que nos leva a crer que a obediência cadavérica, ao ser um predicativo comum a ambos, é conditio per quam da burocracia como aparelho organizacional e forma de governo.
} 
parte da mais baixa hierarquia dos porteiros, porquanto existem incontáveis outros em cada corredor da lei, além dos funcionários do médio e alto escalão, os quais sequer ousa conhecer; 4) "Onde se trata do cumprimento da obrigação, ele não se deixa comover, nem se exasperar" (KAFKA, 2020, p. 248), o que fica comprovado pelo fato de que nenhuma das tentativas do camponês de adentrar no recinto foi exitosa.

Por outro lado, a entrada na lei era proibida tanto ao porteiro quanto ao camponês. 0 primeiro, na verdade, sabia sobre a norma a qual servia apenas o indispensável ao exercício do seu posto. Porém, o fato de ser seu funcionário o situava em uma posição privilegiada, pois ele se sentia parte desta lei sobre-humana. 0 porteiro "é funcionário da lei, portanto pertence à lei, se afasta do veredito humano. Estar preso pelo ofício, ainda que seja apenas à entrada da lei, é incomparavelmente mais do que viver livre no mundo. 0 porteiro foi contratado pela lei para exercer sua função; duvidar de sua honra seria duvidar da própria lei” (KAFKA, 2020, p. 253).

A lei descrita pela lenda não deve ser submetida à luz da publicidade. Ao contrário, sua pureza residiria justamente no fato dela não poder ser completamente conhecida, motivo pelo qual não há espaço para defesa nos seus processos, mas apenas para sua aplicação, realizada sob a forma de acusação. Dessa feita, não era possível se defender (afinal, isso seria feito perante quem? Recorrendo a qual instituição?), até porque os autos do processo, que podiam mudar de uma hora para outra, "não eram acessíveis ao acusado" (KAFKA, 2020, p. 139), de modo que "a única coisa sensata a fazer é se conformar com as condições vigentes, sem criticá-las" (ARENDT, 2008, p. 97).

A lei que Kafka retrata remonta à necessidade. “A força da máquina em que K. de $O$ Processo é apanhado reside nessa aparência de necessidade, de um lado, e na admiração das pessoas pela necessidade, de outro" (ARENDT, 2008, p. 97). Como estas normas movimentavam a máquina burocrática descrita em $O$ Processo, ao passo em que eram ativadas às expensas deste gigantesco aparato, os homens que tentavam resistir aos seus ditames pareciam se contrapor a uma prescrição divina, assim como os seus funcionários se deixavam, gradativamente, de ser homens para se converter em agentes da necessidade. "Como funcionário da necessidade, o homem se torna um agente da lei natural da ruína, se degradando ao nível de um instrumento 
natural de destruição, a qual pode ser acelerada pelo uso pervertido das capacidades humanas" (ARENDT, 2008, p. 101).

Ao servirem a estatutos sobre-humanos e ao se identificarem completamente com suas funções, os personagens kafkianos eram incólumes ao erro, pois seu equívoco apontaria falhas do próprio sistema, o que era impossível. Para Arendt, “todos os membros dessa sociedade [...] lutam por uma espécie de perfeição sobre-humana" (2008, p. 102). A ausência da possibilidade, tão humana, do equívoco indica que não mais homens compunham a sociedade, mas indivíduos que, ao se conceberem como semideuses, para os quais as atividades que tornam os homens qua homens - a ação, o discurso e o pensamento - eram supérfluas, se metamorfosearam em animais movidos pela sujeição à voracidade das necessidades vitais e por sua incapacidade de se distinguir.

Em uma sociedade em que todos possuem papeis determinados pelo trabalho, o perigo reside justamente na indefinição de sua posição, já que todos “carecem de um lugar definido no mundo de quem tem emprego fixo e regular" (ARENDT, 2008, p. 102). Nessa massa de funcionários descrita por Kafka, ninguém desvela o seu quem: nem os funcionários do alto escalão ${ }^{10}$, que aparecem apenas como lendas inatingíveis, nem os membros mais baixos da hierarquia, que de bom grado se reduzem às suas funções.

Por isso os heróis kafkianos não têm nome, apenas iniciais: em um não-mundo, os homens hermeticamente ajustados às organizações abdicam das idiossincrasias que tornam os indivíduos singulares. As consequências desta metamorfose, que converte homens supérfluos em funcionários devotados de máquinas burocráticas regidas pela necessidade, membros de uma sociedade que se instaurou em substituição a Deus, porém mantendo a crença em legislações eternas e imutáveis que emanavam de movimentos necessários - como a lei da história e da natureza que regeram os governos totalitários -são descritas em Origens do totalitarismo, quando Arendt destaca que:

\footnotetext{
10 Pode-se estabelecer aqui a relação entre os funcionários do alto escalão kafkianos, cuja face jamais é conhecida, e Lorde Cromer, cônsul-geral britânico no Egito, que exercia as funções de Chefe de Estado, sem que isso fosse de conhecimento da população, alheada dos assuntos públicos do país. Isso só era possível porque ele "permanecia mais ou menos oculto e puxava os cordões" (ARENDT, 2011, p. 244) da política nos bastidores, longe da luminosidade dos espaços de aparência e debate publicizados.
} 
Jogando o Grande Jogo, o homem pode sentir que vive a única vida que vale a pena, porque se despe de tudo o que ainda pode ser considerado acessório. A própria vida parece ficar para trás [...] quando ele se liberta de todos os laços sociais comuns - família, ocupação regular, objetivos definidos, ambições e o lugar numa comunidade [...]. 0 que faz o jogo tão perigosamente semelhante à própria vida é o fato de não ter um objetivo final (ARENDT, 2011, p. 245).

Uma leitura concomitante feita por Arendt sobre o romance é aquela que remonta ao sentimento de culpa que, durante o processo, ganha força em K. ${ }^{11}$ : não teria ele feito mesmo nada demais? Será que alguma mácula não havia feito dele um inimigo do sistema, tornando o processo legítimo? A verdade é que, se sua condenação já era um fato acabado, qualquer resistência seria impossível, pois "faz parte do modo como são conduzidas as coisas nesse tribunal o fato de a gente não apenas ser condenado inocentemente, mas também sem saber" (KAFKA, 2020, p. 68).

O sentimento de culpa que gradativamente passou a ser marcante em K. "desencadeia uma evolução interna própria, transforma e molda sua vítima até que esteja pronta para enfrentar o julgamento" (ARENDT, 2008, p. 98). É a comiseração por si mesmo, nessa leitura, que faz com que os indivíduos "se ajustem igualmente bem ao papel de carrasco e ao de vítima" (ARENDT, 2011, p. 520) e que se reverberou no protagonista d' O Processo também sob a forma de uma inquietação e satisfação inexplicáveis por fazer parte de tão nobilíssima causa, mesmo que seja no papel de condenado. Nesse horizonte de argumentação, o banqueiro Joseph K. guarda semelhanças com o protagonista de Crime e castigo, de modo que "K., [é o] Raskolnikov do mundo administrado" (BAECKES in KAFKA, 2020, p. 262).

Arendt não acredita que Joseph K. era uma exceção. Antes ocupado com as negociações do banco no qual trabalhava (até mesmo suas horas de folga giravam em torno das relações oriundas de suas funções laborais), ele nunca havia se indagado sobre questões como culpa, lei e necessidade, o que "o lançou em confusão, fazendo com que interprete erroneamente o mal pérfido e organizado do mundo circundante como uma espécie de expressão necessária daquela culpa geral, que é inofensiva se comparada à vontade doentia que converte mentir num

\footnotetext{
11 "Minha inocência não simplifica o caso [...]. Tudo depende de muitas coisas sutis, nas quais o tribunal se perde. Mas no final surge, de alguma parte de onde não havia, uma grande culpa" (KAFKA, 2020, p. 174).
} 
princípio universal" (ARENDT, 2008, p. 98). Na verdade, K. demonstra que "um homem apanhado pela máquina burocrática já está condenado" (ARENDT, 2008, p. 99).

0 criminoso sem crime de Kafka se assemelha à categoria de inimigo objetivo cunhada por Arendt ${ }^{12}$. Ambos se caracterizam pela ausência de ofensa presumível, por serem indésirables e executáveis sob a justificativa de fazer cumprir as sentenças dadas de antemão pelas normas sobre-humanas. Os dois foram condenados nos tribunais superiores da necessidade, nos quais a luminosidade ínsita às legislações civis é desnecessária. Nos laboratórios da dominação total, os campos de concentração, o criminoso sem crime kafkiano e o inimigo objetivo de Arendt são uma só pessoa, reduzida a um feixe de reações, cuja despersonalização faz com que "morta a individualidade nada resta senão horríveis marionetes com rostos de homem [...] reagindo com a mesma previsibilidade mesmo quando marcham para a morte" (ARENDT, 2011, p. 506).

Ademais, ambos estão submetidos a regimes burocráticos cujo objetivo é a dominação total e são comparados a cães - seja o cão de Pavlov, seja Joseph K., cujo algoz, após executá-lo, afirmou: “Como um cão! É como se a vergonha devesse sobreviver a ele” (KAFKA, 2020, p. 262). Quando a lei se vincula à administração da ilegalidade e à execução de crimes, culpa e inocência viram conceitos destituídos de significado e de aplicabilidade, pois “'culpado' é quem estorva o caminho do processo natural ou histórico que já emitiu julgamento quanto [...] a quem é 'indigno de viver"' (ARENDT, 2011, p. 517). Ao não conhecer quem serão os próximos criminosos sem crime, os potenciais inimigos objetivos do regime, instaura-se um estado de terror generalizado que, ao minar os homens de sua capacidade de ação, se estabelece como princípio de movimento dos governos totais.

Arendt (2008) relata que, desde o seu lançamento, O Processo foi compreendido como uma crítica à burocracia austro-húngara e à dominação que o funcionalismo público exercia sobre os diversos grupos nacionais que ali residiam. Kafka, funcionário da companhia de seguros Arbeiter-Unfall-Versicherungsanstalt, conhecia a fundo as dificuldades que os homens que se achavam enredados nos labirintos burocráticos enfrentavam, posição privilegiada que lhe

12 Para um aprofundamento da análise da categoria de inimigo objetivo em Arendt, cf. (AGUIAR, 2011). 
possibilitou denunciar a desumanização que esta forma de governo propicia. Porém, os leitores de seu tempo, mesmo fascinados por sua arte narrativa, não conseguiram compreender o perigo que seus textos denunciavam, pois a burocracia não lhes parecia um mal tão grande. Por isso consideraram que o organismo medonho e mortal descrito em O Processo só podia se referir a alguma realidade teológica, equívoco que, para a autora, "revela mais sobre si do que sobre Kafka - revela sua adequação a essa sociedade” (ARENDT, 2008, p. 99). Para Anders (2007, p. 20), “o espantoso, em Kafka, é que o espantoso não espanta ninguém”.

\section{As duas leituras arendtianas sobre $\boldsymbol{O}$ Castelo}

O Castelo narra a história de um agrimensor, cujo nome é K., que chegou a uma aldeia a partir do chamado dos governantes locais, funcionários do Castelo, para trabalhar na medição dos terrenos da região. Porém, sua chegada já deixa entrever a suspeição que perpassará a história - ninguém reconhece a convocação que o trouxe ao local, o que faz com que ele seja reiteradas vezes "recebido e repelido sem maiores explicações" (CARONE in KAFKA, 2000, p. 470).

Sua existência torna-se inexistência13: ele não faz parte da aldeia e nem do Castelo, e este não-pertencimento, sinônimo de não-ser, torna ineficazes todas as suas tentativas de se estabelecer no local, formar família, trabalhar e ser um cidadão comum, indistinguível. Mesmo com seus esforços para se assimilar à aldeia (incluindo se sujeitar à função de bedel do colégio e aos desmandos do professor, interventor destinado para mantê-lo sob controle), ele permanece indesejável, pois:

aos olhos dos burocratas menores, sua existência era devida meramente a um erro burocrático, enquanto seu status como cidadão era de papel, enterrado em pilhas de documentos [...]. Ele é acusado continuamente de ser supérfluo, 'indesejado e no caminho de todos', de precisar depender, como estrangeiro, da magnanimidade de outras pessoas e de ser tolerado somente em razão de um misterioso ato de graça (ARENDT, 2016, p. 515).

\footnotetext{
${ }^{13}$ Segundo Carone (in KAFKA, 2000), a suspensão - e suspeição - da existência de K. aponta para um sofrimento sem previsão de término, lacuna no tempo cuja duração se desvela como um presente contínuo, um agora doloroso que se repete indefinidamente. Essa perpetuação do sofrimento causado pela não-existência de K. aponta para a impossibilidade de distinguir passado, presente e futuro, diferenciações temporais que se reduzem a um pesar interminável - indistinção temporal que remete ao Ele.
} 
Porém, K. não está disposto a aceitar que seus direitos básicos sejam concedidos sob a forma de favores assentidos pelos funcionários do Castelo ${ }^{14}$ : afinal, ele era um sujeito livre, que havia, por sua vontade, deixado sua cidade natal para trabalhar na região. Estabelece-se, assim, uma relação antagônica formada por K., que lutava para que seus direitos fossem assegurados, e pela organização que inviabilizava sua assimilação, cujos funcionários "sempre tinham de defender coisas remotas e invisíveis em nome de senhores remotos e invisíveis" (KAFKA, 2000, p. 91). Para Boa (2002), a atitude de K., que contrasta com o aspecto feudal e gris que caracteriza o Castelo e a aldeia, aponta para o dilema do homem moderno, "que busca sustentar sua identidade por meio da integração em uma comunidade" (BOA, 2002, p. 62).

Entretanto, esse esforço por ser reconhecido como cidadão se confronta com um contexto no qual não há diferença entre autoridade e ingerência sobre a vida (zoé). Nesse sentido, não apenas o não-pertencimento de K. faz dele um estranho, mas o fato de ser "o único ser humano normal e saudável onde tudo o que é humano e normal, o amor, o trabalho, o companheirismo, foi arrancado das mãos dos homens para se tornar uma dádiva concedida de fora - ou, como diz Kafka, do alto" (ARENDT, 2008, p. 100).

A primeira leitura arendtiana sobre $O$ Castelo identifica no romance os dilemas ínsitos ao povo judeu, como a assimilação, o desejo de fazer parte de uma comunidade e de ser um cidadão indistinguível. Estes, no romance, se contrapõem às reiteradas demonstrações de que K. não é bem-vindo e de que todos - seja da aldeia, seja do castelo - ficariam melhores com a sua ausência. Nesse sentido, “como é possível alguém alegrar-se com o mundo, a não ser quando se refugia nele?" (Kafka, 2011, aforisma 25).

Assim como o protagonista anônimo de Descrição de uma luta, o agrimensor K. é um pária, porquanto utiliza o pensamento e o questionamento como instrumentos de autopreservação, enfrentando, de modo aberto, a sociedade aldeã e os funcionários do Castelo. Para Arendt (2016), ambos apresentam os predicativos com os quais Kafka retratava seus personagens marginais.

\footnotetext{
14 “Não quero graça nem favores do castelo, mas reivindico apenas meus direitos” (KAFKA, 2000, p. 93).
} 
O que Kafka descreve é o verdadeiro drama da assimilação, não seu equivalente distorcido. Ele fala ao judeu médio de pouca importância que realmente não quer nada além de seus direitos enquanto ser humano: casa trabalho, família e cidadania. Ele é retratado como se estivesse sozinho na Terra, o único judeu em todo o mundo - completamente, desoladamente só. Aqui, também, Kafka pinta um quadro fiel à realidade e ao problema humano básico que a assimilação envolve, se levada a sério. Pois na medida que o judeu busca tornar-se indistinguível de seus vizinhos gentios, ele deve comportar-se como se estivesse inteiramente sozinho; deve separar-se da companhia, de uma vez por todas, daqueles que são como ele. (ARENDT, 2016, p. 516)

Na leitura arendtiana d' $O$ Castelo, a determinação de K. para se tornar indistinguível, aliada ao seu interesse por universais, ou seja, pelos direitos aos quais todos os homens deveriam ter acesso, fazem dele um homem de boa vontade. Mesmo quando perde a inocência do pária ${ }^{15}$, ele continua sua luta por viver uma existência normal, porém, agora consciente de que tornar-se indistinguível não bastaria para que ele tivesse acesso às prerrogativas que pleiteava.

Na verdade, a existência normal que ele buscava era excepcional: enquanto é característico do homem de boa vontade determinar os rumos de sua vida, no controle exercido pelo Castelo, o que deveria ser um acontecimento natural se converte em benção ou maldição, ambas oriundas de deliberações cuja origem jamais pode ser conhecida pelos homens de boa vontade. Assim como a máquina descrita em $O$ Processo, o regime d' O Castelo também é inacessível. Porém, frente a este contexto similar, os dois K.'s adotam posturas diferentes.

Se o banqueiro K. de $O$ Processo foi considerado o Raskolnikov da sociedade administrada, o agrimensor K. de $O$ Castelo é o Fausto kafkiano, o Prometeu moderno que permanece acorrentado aos procedimentos que decidem quem vive e quem morre (CARONE in KAFKA, 2000). Porém, na leitura de Arendt sobre o romance, há uma diferença entre ambos: enquanto o primeiro acaba sucumbindo às leis da necessidade, o segundo não se submete a elas porque seu interesse "por universais, por aquelas coisas a que todos os homens têm direito natural" (ARENDT, 2008, p. 99) faz com que ele mantenha seu empenho por ter seus direitos assegurados.

\footnotetext{
15 Segundo Arendt (2016, p. 519), K. "perde a inocência do pária" quando conversa com a irmã de Barnabás e identifica que os destinos dos moradores da aldeia eram ditados pelos procedimentos do Castelo. Uma das irmãs do mensageiro relata a K. a situação da família: "excluíram-nos da sociedade [...], já não falam de nós como pessoas, nosso nome de família não foi mais mencionado [...]. Tudo o que nós éramos, tudo o que nós tínhamos, encontrava o mesmo desprezo" (KAFKA, 2000, p. 314).
} 
K. permanece em sua luta por se inserir e seus esforços, ao passo que selam seu destino, nos direcionam para a segunda leitura empreendida por Arendt. 0 herói do romance morre de exaustão devido às suas incontáveis e fracassadas tentativas em ser reconhecido como cidadão16. A morte do agrimensor lembra o aforisma 34 do autor, no qual lê-se que: "Sua exaustão é a do gladiador após a luta, seu trabalho foi caiar o canto do escritório de um funcionário" (KAFKA, 2011, aforisma 34).

Diferente da morte do K. de $O$ Processo, o agrimensor d' $O$ Castelo não se submeteu a códigos supraconstitucionais, assim como não lhe sobreveio nenhuma culpa. Mesmo permanecendo como forasteiro e sem ter acesso aos universais que ele exaustivamente reivindicou, sua resistência fez com que a vergonha não sobrevivesse a ele (como pressagiado pelos algozes do primeiro romance), tornando-o a prova de que "pode valer a pena lutar pelos direitos humanos, que o domínio do Castelo não é uma lei divina e, por conseguinte, pode ser atacado" (ARENDT, 2008, p. 100). Entretanto, sua morte demonstra que "o que ele se esforçou para alcançar estava além das forças de qualquer homem singular" (ARENDT, 2016, p. 520).

Segundo Anders (2007, p. 97), o cenário retratado em $O$ Castelo aponta para a construção de "um mundo do poder total e totalitariamente institucionalizado", enquanto o protagonista representa o homem comum, cuja existência é ditada pela burocracia. Kafka percebeu que esta nova forma de governo se caracteriza pela desfiguração dos homens e por sua tendência em engolfar, com igual força, as esferas pública e privada.

É muito provável que o leitor das histórias de Kafka passe por um estágio em que se incline a considerar este mundo de pesadelo algo trivial, mesmo que, talvez, um prenúncio psicologicamente interessante de um mundo futuro. Mas esse mundo de fato veio a existir. A geração dos anos 1940, e sobretudo quem teve a duvidosa vantagem de viver sob o regime mais terrível já criado pela história, sabe que o terror de Kafka representa adequadamente a natureza verdadeira dessa coisa chamada burocracia - a substituição do governo pela administração e das leis por decretos arbitrários. Sabemos que a construção de Kafka não foi um pesadelo (ARENDT, 2008, p. 101).

\footnotetext{
16 No final do romance, o único lugar em que K. foi autorizado a ficar era a cantina de uma das hospedarias da aldeia, de modo que nem os outros cômodos da estalagem poderia utilizar: "eu, legalmente, nem tenho direito de permanecer em outra parte, senão nessa cantina" (KAFKA, 2000, p. 358).
} 
Enquanto a primeira leitura de Arendt sobre $O$ Castelo se ampara na identificação do herói kafkiano como um personagem tipicamente judeu, a segunda aponta para os perigos ínsitos à elevação da burocracia como forma de governo, o que já havia sido prenunciado em $O$ Processo. Para compreendê-los, recorreremos a três personagens: os ajudantes de K., o mensageiro Barnabás e o castelão.

Os primeiros foram enviados ao agrimensor pelo Castelo com o objetivo de auxiliá-lo em seus trabalhos - o que torna sua função ilógica, já que o único trabalho que este exerceu foi de bedel no colégio. Eles eram "de uma ridícula obediência" (KAFKA, 2000, p. 36), que beirava à infantilidade: estavam sempre prontos para executar qualquer função irrefletidamente. Os ajudantes eram também eram indistinguíveis, constatação que K. faz ao afirmar que: "Assim são, pois, os funcionários: semelhantes exemplares existentes" (KAFKA, 2000, p. 232).

O outro personagem é Barnabás, o mensageiro que nem conhecia o conteúdo dos documentos que entregava e nem os empregados do Castelo, pois "em geral, os funcionários se substituem mutuamente e fica difícil descobrir a incumbência de tal ou qual funcionário" (KAFKA, 2000, p. 226). Como poderia, então, o mensageiro exercer seu ofício de um modo digno, se sequer conhece a quem irá se reportar?

Através do personagem pode-se identificar que o ritualismo e a divisão dos espaços, predicativos ínsitos à burocracia, são as faces da mesma moeda. Mesmo conhecendo pouco as repartições, Barnabás afirmava que os escritórios continham barreiras que tornava o funcionamento da máquina intransponíveis ao público e aos funcionários do baixo escalão. As decisões eram tomadas neste espaço inacessível, de modo que eram desconhecidas tanto as faces de onde emanam as ordens quanto os espaços nos quais os decretos eram protocolados. Desse modo, o mensageiro "chega a certos escritórios, mas estes não são mais do que uma parte de sua totalidade, porque depois existem umas barreiras e atrás destas existem mais escritórios ainda [...]. Além disso, no castelo sempre se é observado" (KAFKA, 2000, p. 212).

O terceiro personagem, o castelão, foi um dos únicos funcionários oficiais com o qual K. teve contato. De pronto, ele afirma ao agrimensor que sua vinda à região é um equívoco ${ }^{17}$

\footnotetext{
17 “O senhor está contratado como agrimensor, mas não precisamos de nenhum agrimensor. Não haveria para este sequer o menor trabalho. As demarcações de nossas pequenas propriedades estão delimitadas, mudanças nas
} 
decorrente de falhas que podem fazer com que "alguma vez que uma das seções ordene isto e outra aquilo; uma não sabe da outra e, embora o controle superior seja de uma precisão extrema, chega demasiado tarde e, assim, produz-se uma pequena confusão" (KAFKA, 2000, p. 86). Entretanto, estas são raríssimas, e K. é uma destas exceções ${ }^{18}$, já que “a autoridade tem por princípio que não se conte com a possibilidade de uma falha. Esse princípio fica justificado pela excelente organização do conjunto [...], é um princípio necessário" (KAFKA, 2000, p. 91).

O diálogo entre os personagens deixa entrever o funcionamento da burocracia local. 0 funcionário explica que as incontáveis repartições são divididas em seções nomeadas por ordem alfabética ${ }^{19}$, de modo que várias delas eram acionadas no correr de cada trâmite processual, sempre obedecendo "a mandatos remotos [...] que não se podiam examinar jamais" (KAFKA, 2000, p. 150). 0 próprio castelão nunca havia visto seu superior, conhecendo-o apenas através da sua assinatura. Frente à constatação de que o que o governava era um gigantesco aparelho em que "como um raio, cai uma resolução precedente de alguma autoridade imprevisível e que mais tarde já não poderá ser identificada, que não deixa de ser, de certo modo, arbitrária" (KAFKA, 2000, p. 95), K. não pôde deixar de identificar o "ridículo embrulho em que em determinadas circunstâncias depende a existência de um homem" (KAFKA, 2000, p. 90).

\section{A título de conclusão: sobre as possibilidades de resistência do homem de boa vontade}

Foi na literatura kafkiana que Arendt encontrou a análise mais sóbria das estruturas que vieram à luz com o advento do totalitarismo 20 . "Na medida em que a vida é um declínio que leva à morte, ela pode ser prevista. Numa sociedade em dissolução, que acompanha cegamente o curso natural da ruína, é possível prever a catástrofe" (ARENDT, 2008, p. 101). Kafka conhecia

\footnotetext{
propriedades raramente se verificam e as pequenas questões de limites nós mesmos arbitramos. Que faremos, pois, com um agrimensor?" (KAFKA, 2000, p. 85).

${ }^{18}$ No mesmo diálogo, porém, o castelão arrazoa que as falhas não são imperfeições, mas consequências da organização: "Se existem escritórios de controle? Existem somente escritórios de controle. Claro que não estão destinados a descobrir falhas no sentido bruto da palavra, posto que tais falhas não se produzem, e mesmo quando alguma vez se produz uma falha, como no seu caso, quem poderia dizer que é uma falha?" (KAFKA, 2000, p. 91).

${ }^{19}$ As seções nazistas também o eram: Eichmann, por exemplo, era responsável pela seção B-IV (ARENDT, 2017).

${ }^{20}$ Canovan (1992) e Bernstein (1996) apontam que as análises da burocracia feitas por Arendt denotam o impacto que os escritos kafkianos exerceram na autora.
} 
esse mundo a fundo, motivo pelo qual sua descrição é dotada de uma clareza assustadora: formado em Direito e trabalhando em uma companhia de seguros, pôde constatar como o labirinto burocrático destitui os homens de seus direitos básicos até exauri-los, como ocorreu com o K. de $O$ Castelo.

Numa sociedade composta por ninguéns, os protagonistas kafkianos são destituídos da singularidade do nome próprio: os K.'s e o Ele são homens comuns, injustiçados, desalojados, excluídos, criminosos sem crime. Se "a palavra ser [sein] significa duas coisas em alemão: estar aí [Dasein] e pertencer-lhe [Ihm gehören]" (KAFKA, 2011, aforisma 46), não pertencer equivale a não-ser. Esta afirmação, que lembra a sentença arendtiana de que ser e (a)parecer coincidem (ARENDT, 2014), aponta para a constatação de que privar os homens de um lugar no mundo equivale a destituir-lhes de qualquer humanidade, e indivíduos "desprotegidos por qualquer lei específica ou convenção política, não são nada além de seres humanos" (ARENDT, 2016, p. 490).

Para Arendt, Kafka também compreende que a salvação, e não a ruína, vem do inesperado, porquanto depende da liberdade humana e do uso de suas capacidades. 0 surpreendente se origina da possibilidade - jamais irremediavelmente perdida - de iniciar algo singular, como a criação de um novo mundo, seja o artificial, fruto da obra do homo faber, seja o comum, efeito da ação e do discurso. É justamente neste ponto que se situa a leitura de Arendt sobre o romance América e do homem como fabricator mundi.

0 romance narra a história de um jovem que, devido a conflitos familiares, é expulso de sua terra natal, partindo rumo a América. Esta mudança lhe permite imaginar a construção de um mundo inaudito, no qual todos são bem-vindos e podem viver "segundo seus talentos, sua inclinação e sua vontade" (ARENDT, 2016, p. 519), e não como alguém excepcional, seja santo, gênio ou louco. Nesse cenário, o homem de boa vontade pode legar algo de si no mundo, ou mesmo fabricá-lo, conforme suas aptidões.

Porém, os leitores mais desavisados poderiam descuidadamente interpretar a apresentação do homem de boa vontade e a possibilidade da construção de um novo mundo, no qual os fabricatores mundi seriam inseridos em comunidades nas quais disporiam do status de cidadão, como o indício de um romantismo idílico presente nas linhas kafkianas. Ao contrário, 
denunciam que tais experiência não são possíveis na estrutura social e política contemporânea, já que "o homem de boa vontade é levado hoje ao isolamento, assim como o estrangeiro-judeu no castelo. Ele se perde - ou morre de exaustão. Pois somente dentro da estrutura de um povo um homem pode viver como um homem entre homens, sem se exaurir" (ARENDT, 2016, p. 523).

Há um ponto em comum entre os K.'s de Kafka: seus heróis anônimos são homens comuns, integrantes de um ideal de humanidade inserido no contexto burocrático. Porquanto a descrição do funcionamento desta máquina é um tema recorrente nas obras do escritor, a possibilidade de resistir a ela, em nome da defesa dos universais - o direito à casa, a possuir uma família, a ter um emprego e, principalmente, a pertencer a uma comunidade que lhe reconheça como cidadão - também aparece em seus textos. Para tanto, Kafka retrata personagens que se caracterizam por sua boa vontade, e não pela adequação irrestrita a este sistema que substitui humanidade por funcionalidade.

Este homem de boa vontade não ambiciona fazer carreira, nem ser funcionário de máquinas burocráticas movidas por leis desconhecidas. E, justamente por isso, ele está fadado a permanecer como estranho, perdido em uma sociedade "que frustra as necessidades mais banais e destrói as mais elevadas intenções do homem" (ARENDT, 2008, p. 103). Nessa conjuntura, em que o pertencimento depende da classe ou da raça, Kafka

queria construir um mundo de acordo com as dignidades humanas, um mundo onde as ações do homem são determinadas por ele mesmo, guiado por leis humanas e não por forças misteriosas que emanam do alto e das profundezas. Além disso, seu desejo mais intenso era fazer parte de um mundo desses - não estava preocupado em ser um gênio ou a encarnação de algum tipo de grandeza. (ARENDT, 2008, p. 107)

Os heróis kafkianos também são anti-heróis, pois se esquivam do que se espera de um protagonista dos romances tradicionais: não ambicionam ser semideuses, não servem a causas ulteriores, tampouco possuem talentos excepcionais, traços que, na verdade, os aproximariam justamente do paradigma de homem que Kafka quer denunciar. Os seus heróis são demasiado humanos e, portanto, cometem atos de covardia, são rebeldes, sentem medo, são fracos, sentem comiseração por si mesmos. Porém, é justamente porque são anti-heróis (e, consequentemente, 
humanos) que se aproximam da verdade sobre a face medonha da sociedade, sobre os perigos ínsitos à burocracia como forma de governo, ou ainda sobre a constatação da condição outlaw dos judeus da época, a qual ele procurou combater através da literatura, do pensamento e do engajamento ativo no mundo, saídas que ele considerava as únicas possíveis.

A construção deste novo mundo somente seria possível com a destruição do antigo e o estabelecimento de um outro, em que o homem de boa vontade pudesse se sentir em casa. Para Arendt, este homem é o único capaz de reconstruir o mundo, alicerçando-o em bases dignas. "E como esses heróis são apenas modelos de boa vontade, permanecendo no anonimato, na abstração genérica, mostrados apenas na função que pode ter a boa vontade neste nosso mundo, seus romances parecem dizer: este homem de boa vontade pode ser qualquer um, talvez até mesmo você ou eu" (ARENDT, 2008, p. 107-108).

\section{Referências}

ADVERSE, H. Arendt e a crítica ao romantismo na biografia de Rahel Varnhagen. Argumentos Revista de Filosofia. Fortaleza, ano 5, n. 9, p. 79-96, 2013.

AGUIAR, O. A. A amizade como amor mundi em Hannah Arendt. $O$ que nos faz pensar? Rio de Janeiro, n. 28, dez. 2011, p. 131-144.

AGUIAR, O. Filosofia e política no pensamento de Hannah Arendt. Fortaleza: Edições UFC, 2001.

ANDERS, G. Kafka: pró \& contra. Os autos do processo. Trad. Modesto Carone. São Paulo: Cosac \& Naify, 2007.

ARENDT, Hannah. A vida do espírito. Trad. Cesar Augusto de Almeida, Antônio Abranches e Helena Martins. $4^{\underline{a}}$ ed. Rio de Janeiro: Civilização Brasileira, 2014.

ARENDT, H. Compreender. Formação, Exílio e totalitarismo. Trad. Denise Bottmann. São Paulo: Companhia das Letras; Belo Horizonte: Editora UFMG, 2008.

ARENDT, H. Diário Filosófico (1950-1973). Trad. Raúl Gabás. Barcelona: Herder, 2006.

ARENDT, H. Eichmann em Jerusalém. Um relato sobre a banalidade do mal. Trad. José Rubens Siqueira. São Paulo: Companhia das Letras, 2017.

ARENDT, H. Entre o passado e o futuro. Trad. Mauro W. Barbosa. 8ae ed. São Paulo: Perspectivas, 2016.

ARENDT, H. Escritos judaicos. Trad. Laura Degaspare Monte Mascaro, Luciana Garcia de Oliveira, Thiago Dias da Silva. Barueri: Amarilys, 2016.

ARENDT, H. Origens do totalitarismo. Anti-semitismo. Imperialismo. Totalitarismo. Trad. Roberto Raposo. São Paulo: Companhia das Letras, 2011.

ARENDT, H. Rahel Varnhagen. A vida de uma judia alemã na época do romantismo. Trad. Antônio Trânsito e Gernot Kludash. Rio de Janeiro: Relume-Dumará, 1994. 
ARENDT, Hannah. Responsabilidade e Julgamento. Trad. Rosaura Einchenberg. São Paulo: Companhia das Letras, 2004.

BENHABIB, S. The reluctant modernism of Hannah Arendt. 2ª ed. Lanham: Rowan \& Littlefield, 2003.

BENJAMIN, W. Magia e técnica, arte e política. Ensaios sobre literatura e história da Cultura. 3aㅡ ed. Trad. Sérgio Paulo Rouanet. São Paulo: Editora Brasiliense, 1987. (Obras Escolhidas Volume I).

BERNSTEIN, R. Hannah Arendt and the jewish question. Cambridge: MIT Press, 1996.

BINDER, H. Kafka-Handbuch. Stuttgart: Alfred Kröner, 1979.

BOA, E. The Castle. In: PREECE, J. (Ed.). The Cambridge Companion to Kafka. Cambridge: Cambridge University Press, 2002.

CANOVAN, M. Hannah Arendt: a reinterpretation of her political thought. New York: Cambridge University Press, 1992.

ECCEL, D. Franz Kafka lido por Hannah Arendt: cultura, formação e política. Revista Aurora, v. 31, n. 52, p. 304-322, 2019.

ERDLE, Birgit R. "Dis/Placing Thought: Franz Kafka and Hannah Arendt". In: COOLS, A.; LISKA, V. Kafka and the Universal. De Gruyter, 2016, pp. 307-20

KAFKA, F. América. Trad. D.P. Skyroski. São Paulo: Nova Época Editorial, 1992.

KAFKA, F. Descrição de uma luta. Trad. Aulyde Soares Rodrigues. Rio de Janeiro: Nova Fronteira, 1985.

KAFKA, F. Diários. 1909-1923. Trad. Sérgio Tellaroli. São Paulo: Todavia, 2021.

KAFKA, F. Essencial. Trad. Modesto Carone. São Paulo: Companhia das Letras, 2011.

KAFKA, F. O Castelo. Trad. Modesto Carone. São Paulo: Companhia das Letras, 2000.

KAFKA, F. O Processo. Trad. Marcelo Baeckes. Porto Alegre: L\&PM, 2020.

KNOTT, M. L. Hannah Arendt liest Franz Kafka 1944. In: ARNOLD, H. L.; HEUER, W. Hannah Arendt. München: Text + Kritik, 2005. p. 150-161.

LAFER, C. Experiência, ação e narrativa: reflexões sobre um curso de Hannah Arendt. Estudos Avançados. São Paulo, v. 21, n. 60, p. 289-304, 2007.

LEIBOVICI, Martine. Le paria chez Hannah Arendt. In: ABENSOUR, Miguel et. al. Ontologie et politique. Actes du Colloque Hannah Arendt. Paris: Éditions Tierce, 1989.

REGO, A.; PINA E CUNHA, M.; WOOD JR., T. Kafka e o estranho mundo da burocracia. São Paulo: Editora Atlas, 2010.

ZWEIG, S. Êxtase da transformação. São Paulo: Schwarcz, 1987.

Recebido em: 08/11/2021

Aceito em: 19/11/2021

\section{Lara Rocha}

Bacharela em Filosofia pela Faculdade Católica de Fortaleza (FCF). Especialista em Ensino de Filosofia pela Faculdade Católica de Fortaleza (FCF). Mestra em Ética e Filosofia Política pela Universidade Federal do Ceará (UFC), com dissertação intitulada "Pensar em tempos sombrios: as implicações políticas do pensamento 
na perspectiva de Hannah Arendt". Doutoranda em Filosofia Política pela Universidade Federal do Ceará (UFC). Bolsista da Coordenação de Aperfeiçoamento de Pessoal de Nível Superior (CAPES). 